\title{
Analysis of graduate programs on the field of curriculum and instruction*
}

\section{Canay DEMİRHAN IŞCAN**}

\author{
Fatma HAZIR BIKMAZ ${ }^{* * *}$
}

\begin{abstract}
This study was conducted to analyze curriculum and instruction (CI) graduate programs from Turkey and abroad by considering certain variables and make recommendations for graduate programs in this field in Turkey. Based on the document analysis method, the study obtained data from printed sources and the official websites of universities. Twenty-seven of the 30 master's level CI programs and 13 of the 16 doctoral level CI programs in Turkey were analyzed. When compared to ALES scores, foreign language scores required for application to graduate programs varied from one graduate school to another. It was found that the compulsory and elective courses offered in CI graduate programs in Turkey were quite similar. Besides, the required number of courses/credits in these programs, program completion times, comprehensive exams, dissertation committees, dissertation processes, and conditions for graduation were common among the different graduate schools examined. The total number of credits needed for graduation from CI graduate programs varied significantly between Turkish and foreign universities. In addition, admissions into foreign programs were based more on statements of purpose, reference letters and publications than exams. The names of foreign programs were varied, which brought diversity in the individual courses offered by them. Finally, it was noteworthy that foreign programs, and particularly doctoral level ones, made use of various committees to evaluate and guide students.
\end{abstract}

Keywords: Curriculum and instruction, curriculum development, graduate education.

\footnotetext{
* Earlier version of this research was presented at The First National Congress on Curriculum and Instruction.

** Assist. Prof. Dr., Ankara University, Faculty of Educational Sciences, Department of Elementary Education, Ankara, Turkey. E-mail:cdemir@education.ankara.edu.tr

*** Assoc. Prof. Dr., Ankara University, Faculty of Educational Sciences, Department of Curriculum, Ankara, Turkey. E-mail:bikmaz@education.ankara.edu.tr
} 


\section{SUMMARY}

Purpose and Significance: Graduate programs in Turkey on curriculum and instruction (CI)/curriculum development sometimes become the source of criticism or comments. These mostly revolve around student admission, program content, quality and assessment of students. This study was designed to analyze CI or program development graduate programs from Turkey and abroad by considering certain criteria, and make recommendations for Turkish graduate programs in these fields.

Method: This is a descriptive study. It utilized the qualitative data collection method of document analysis, and collated printed sources as well as Internet documents about graduate programs in the two mentioned fields of study in Turkey and other countries. Internet documents were the official university websites.

For the study, 27 out of 30 master's level CI programs and 13 out of 16 doctoral level programs in Turkey were analyzed. When determining foreign programs to analyze, the top 100 world universities in 2010 that offer graduate programs in $\mathrm{CI}$ or a relevant field were selected. According to this criteria, a total of 11 graduate programs from the US and Canada were included in the study. The analyses were based on application requirements, student admission, and curricula.

Results: Thirteen out of the 27 master's level programs in Turkey required the minimum foreign language score determined by the university senate for application to the program. Seven of the 13 doctoral level programs mentioned that they required a foreign language score of at least 55 for application. In addition, 21 of the 27 master's level programs and 8 of the 13 doctoral level programs stated that they required an ALES score of at least 55. Only 5 of the master's level programs and 8 doctoral level programs supplied information about the CGPA required from applicants, all of which were different.

The courses offered in CI graduate programs were quite similar. The most similar compulsory course was scientific inquiry, while the most common subject area course was Program Development and Evaluation in Education. Among elective courses, In-Service Training, Program Evaluation and Comparative Education, Problems of the Turkish Educational System, Comparative Education, and New Trends in Curriculum Development were common.

The principles outlined in the Graduate Education Directive issued by the Turkish Higher Education Council about program completion times, comprehensive exam, dissertation committees, dissertation process and 
graduation were reflected in the directives of all graduate schools. Completion of 21 credits was required for graduation from 21 out of 27 master's level CI programs and 9 out of 13 doctoral level CI programs.

The 11 foreign universities that were examined required resumes, statements of purpose, transcripts, reference letters, GRE and TOEFL scores, 1 or 2 years of teaching experience or professional experience in the field for application to master's and doctoral level programs. In addition, doctoral programs also required a master's thesis or project, or a single-authored scientific publication. Master's or doctoral program completion time was mentioned as total hours, units or credits in different universities. Foreign doctoral programs require practices such as a research project or publication from project in addition to a dissertation, and successful completion of an additional exam other than the comprehensive exam. Doctoral programs abroad also had "dissertation reading committees" before the preparation of a dissertation, "evaluation committees" afterwards, or committees to supervise students from admission to the program onwards. Different from the programs in Turkey, those abroad emphasized multiculturalism, national exams, gifted students, and regional systems, courses that combine real-life community problems and curricula, and practicum and research classes particularly in doctoral programs.

Discussion and Conclusions: Foreign language scores required for application to graduate programs varied from one program to another, more than the ALES scores required. The compulsory and elective courses offered in CI graduate programs in Turkey were quite similar. Besides, the required number of courses/credits in these programs, program completion times, comprehensive exams, dissertation committees, dissertation processes, and conditions for graduation were common among the different graduate schools examined. The total number of credits needed for graduation from CI graduate programs varied significantly between Turkish and foreign universities. In addition, admissions into foreign programs were based more on statements of purpose, reference letters and publications. The names of foreign programs varied, which brought diversity in the individual courses offered by them. Finally, it was noteworthy that foreign programs, and particularly doctoral level ones, made use of various committees to evaluate and guide students. 


\title{
Eğitim Programları ve Öğretim Alanında Lisansüstü Eğitim Programlarının Analizi*
}

\section{Canay DEMIRHAN ISTCAN ${ }^{* * *} \quad$ Fatma HAZIR BIKMAZ ${ }^{* * * *}$}

\begin{abstract}
ÖZ. Bu araştırma, EPÖ ya da eğitimde program geliştirme alanında Türkiye'de ve yurt dışındaki mevcut lisansüstü eğitim programlarını belirli ölçütlere göre analiz etmek amacıyla gerçekleştirilmiştir. Buradan yola çıkarak EPÖ alanındaki lisansüstü programların çeşitli öğeleri için durum tespiti yapılıp, önerilerin geliştirilmesi düşünülmüştür. Doküman inceleme yönteminin kullanıldığı bu araştırmada veriler, basılı kaynaklar ve üniversitelerin resmi internet sayfalarından elde edilmiştir. Araştırma sonucunda, Türkiye'de EPÖ yüksek lisans programlarının 30'undan 27'sine, doktora programlarının ise 16 'sından 13'üne ulaşılabilmiştir. Lisansüstui programlara başvuruda yabancı dil puanı, ALES puanından farklı olarak, enstitüden enstitüye çeşitlilik göstermiştir. Türkiye'de EPÖ lisansüstü programlarında açılan zorunlu ve seçmeli derslerin birbirine oldukça benzer olduğu belirlenmiştir. Bu programlarda alınması gereken ders/kredi sayısı, programları tamamlama süresi, yeterlik snnavı, tez izleme komitesi, tez süreci ve sonuçlanması ile ilgili koşullar enstitüler arasında ortaklık göstermiştir. EPÖ lisansüstü programlarında alınması gereken toplam krediler açısından, Türkiye'deki üniversitelerle yurt dışındakiler arasında önemli farklılık gözlenmektedir. Ayrıca yurt dışındaki programlara başvuruda sınavlardan çok niyet, referans mektupları ve yayınlar ön plana çıkmaktadır. Yurt dışındaki programların isimleri farklılık göstermekte, buna göre üniversiteler arasında derslerde çeşitlilik gözlenmektedir. Ayrıca yurt dışnda özellikle doktora programlarında öğrenciyi değerlendirmek ve ona rehberlik etmek üzere oluşturulan çeşitli komiteler göze çarpmaktadır.
\end{abstract}

Anahtar Sözcükler: Eğitim programları ve öğretim, program geliştirme, lisansüstü eğitim.

\footnotetext{
* Araştırmanın önceki versiyonu 13-15 Mayıs 2010 tarihinde düzenlenen 1. Ulusal Eğitim Programları ve Öğretim Kongresi'nde sunulmuştur.

** Yard. Doç. Dr., Ankara Üniversitesi, Eğitim Bilimleri Fakültesi, İlköğretim Bölümü, Ankara, Türkiye. E-posta:cdemir@education.ankara.edu.tr

*** Doç. Dr., Ankara Üniversitesi, Eğitim Bilimleri Fakültesi, Eğitim Programları Bölümü, Ankara, Türkiye. E-posta: bikmaz@education.ankara.edu.tr
} 


\section{GİRIŞ}

Lisansüstü eğitim örgün eğitim sisteminin bir diploma ile sonuçlanan son aşamasıdır. Varış (1973a) bu aşamayı, bir alanda derinlemesine çalışmak suretiyle, lisans eğitiminden daha yüksek düzeyde bilgi ve etkinliğe sahip olan yüksek ihtisas gücünü yetiştiren kademe olarak tanımlamıştır. Oğuzkan (1981) ise lisansüstü eğitimi, lisans derecesi almış olanlara ilgi duydukları bir bilim dalında yüksek lisans ve doktora öğrenimini yaparak uzmanlaşma olanağı sağlamak üzere düzenlenen bir eğitim olarak tanımlamaktadır. 1983 yılında kabul edilen Lisansüstü Eğitim-Öğretim Enstitülerinin Teşkilat ve İşleyiş Yönetmeliği'nde, "lisansüstü programı; yüksek lisans, doktora veya sanatta yeterlik unvanlarına yönelik belirli sayıda ve belirli muhteva ve adları taşıyan zorunlu ve seçmeli dersler ile doktora yeterlik sınavı, sanat yeterliği sınavi, tez, sanat eseri ve uygulamalardan oluşur" şeklinde tanımlanmıştır (YÖK, 1983; Madde 7)

Türkiye'de 1960'lı y1llara kadar yükseköğretim, lisans ve tıpta uzmanlık veya doktora olmak üzere iki aşamalı olarak düzenlenmiştir (Sağlam, 2007). Resmi olarak ilk kez 1973 yılında kabul edilen 1739 sayılı Milli Eğitim Temel Kanunu'nun 37. maddesinde, “yüksek öğretim, milli eğitim sistemi çerçevesinde, öğrencileri lisans öncesi, lisans ve lisansüstü seviyelerde yetiştiren bir bütünlük içinde düzenlenir" şeklinde yer almıştır. Yine aynı yılda çıkarılan 1750 sayılı Üniversiteler Kanunu ile de üniversiter öğretim; temel bilimler, lisans, yüksek lisans, uzmanlık ve doktora olmak üzere beş düzeye ayrılmıştır (Kısakürek, 1976). Böylece, ön lisans ve yüksek lisans programları da yükseköğretim sistemi içinde yer almıştır (Sağlam, 2007). Yetmişlerden itibaren YÖK yasasının kabulüne kadar olan dönemde lisansüstü eğitim, fakültelerde kürsü anlayışına dayalı olarak yürütülmüş ve 1981 yılında 2547 sayılı yasanın kabulünden sonra da Yüksek Öğretim Kurulu (YÖK) tarafından hazırlanan "Lisansüstü Eğitim Yönetmeliği” ile bu sorumluluk enstitülere devredilerek lisansüstü eğitim farklı bir şekilde kurumsallaştırılmıştır (Güven, 2010). Aynı yıl yürürlüğe giren "Üniversitelerde Akademik Teşkilat Yönetmeliği" ve 1983 yılında yürürlüğe giren "Lisansüstü Eğitim Öğretim Enstitülerinin Teşkilat ve İşleyiş Yönetmeliği" ile hem enstitülerin yapısı belirlenmiş hem de işleyiş̧inde beraberlik sağlamak amaçlanmıştır (Karakütük, 2006).

Lisansüstü eğitim yönetmeliği çerçevesinde yüksek lisans programları tezli ve tezsiz olarak iki farklı biçimde tanımlanmıştır. Tezli yüksek lisans programının amacı, öğrencinin bilimsel araştırma yaparak bilgilere erişme, bilgiyi değerlendirme ve yorumlama yeteneğini kazanmasını sağlamaktır. $\mathrm{Bu}$ program toplam yirmi bir (21) krediden az olmamak koşuluyla en az yedi adet ders, bir seminer dersi ve tez çalışmasından oluşur. Seminer dersi ve tez 
çalışması kredisiz olup başarılı veya başarısız olarak değerlendirme söz konusudur. Öğrenci, en geç üçüncü yarıyılın başından itibaren her yarıyıl tez çalışmasına kayıt yaptırmak zorundadır. Tezsiz yüksek lisans programının amacı ise, öğrenciye mesleki konuda derin bilgi kazandırmak ve mevcut bilginin uygulamada nasıl kullanılacağını göstermektir (YÖK, 1996).

Aynı yönetmelikte doktora programının amacı, öğrenciye bağımsız araşıırma yapma, bilimsel olayları geniş ve derin bir bakış açısı ile irdeleyerek yorum yapma ve yeni sentezlere ulaşmak için gerekli adımları belirleme yeteneği kazandırmak olarak belirlenmiştir. Doktora derslerinin ve yeterlik sınavının başarıyla tamamlanmasının ardından hazırlanacak tezin, bilime yenilik getirme, yeni bir bilimsel yöntem geliştirme ve bilinen bir yöntemi yeni bir alana uygulama niteliklerinden birini yerine getirmesi koşulu aranmaktadır (YÖK,1996).

Yüksek lisans ve doktora programları için YÖK'ün belirlediği koşullardan bazıları -programlara öğrenci kabulü, ön koşullar, sınavlar, uygulanan programlar gibi unsurlar- üniversitelere göre değişiklik gösterebilmektedir. Ancak, enstitülerin hazırlayacağı yönetmeliklerde belirtilecek koşulların, YÖK'ün Lisansüstü Eğitim Yönetmeliği'nde belirlenen koşulları altında olmaması gerekmektedir.

Türkiye' de bugün üniversitelerin sosyal bilimler ya da eğitim bilimleri enstitülerine bağlı olarak yürütülen Eğitim Programları ve Öğretim (EPÖ), ilk olarak Ankara Üniversitesi Eğitim (Bilimleri) Fakültesi'nde bir lisans bölümü olarak 1965 yılında hizmet vermeye başlamıştır. 1969 yılından itibaren ise, oluşturulan "Lisansüstü Eğitim Komisyonu" (Kavcar, 1976) ile bu alanda lisansüstü eğitim programları uygulanmaya başlamıştır. Hazırlanan yönetmelikte, yüksek lisans öğrencileri 30 kredilik ders almak, derslerin sınavını vermek ve 6 kredi değerinde tez hazırlamakla yükümlü tutulmuştur. Otuz (30) kredinin, 15 kredisinin alan derslerinden 15 kredisinin de diğer alanlardan alınması gerekmekteydi (Karakütük, 2009). Doktora programları için belirlenen kredi miktarı 42'dir. Bunun, 15 kredisini alan dersi, 15 kredisini yan alan dersleri ve 12 kredisini de doktora tezi oluşturmaktadır (Karakütük, 2009). Böylece, eğitim alanındaki yüksek lisans ile doktora arasındaki temel farklılığın tez çalışmasına atfedilen değer olduğu gözlenmektedir. Bu tarihlerde Ankara Üniversitesi Eğitim (Bilimleri) Fakültesi'nde EPÖ, Eğitim Yönetimi ve Teftişi, Eğitim Psikolojisi, Halk Eğitimi ve Özel Eğitim olmak üzere beş alanda lisansüstü eğitim çalışmaları yürütülmüş̧ür (Taymaz, 2007). EPÖ-Program Geliştirme alanında uygulanan yüksek lisans programı ilk mezunlarını 1971 yılında, doktora programı ise 1974 yılında vermiş̧ir. Eğitim fakültesi sorumluluğunda yürütülen lisansüstü programı yanında sadece lisansüstü eğitim vermek amacıyla kurulan mezuniyet sonrası ya da lisansüstü eğitim fakülteleri de 
kurulmuştur. Hacettepe Üniversitesi'nde lisansüstü eğitim amaciyla kurulmuş olan Mezuniyet Sonrası Eğitim Fakültesi (1967) ile Ortadoğu Teknik Üniversitesi Lisansüstü Eğitim Fakültesi’nin, Çukurova Üniversitesi Mezuniyet Sonrası Yüksekokulu'nun yüksek lisans ve doktora programları da (Sağlam, 2010) bu alanın bilimsel anlamda güçlenmesine önemli katkılar getirmiştir. 28.03.1983 tarih ve 2809 sayılı yasa ile yalnız lisansüstü eğitim vermek amacıyla kurulmuş olan kurumlar kaldırılmıştır (Karakütük 2002, 2009).

1997 yılında MEB-YÖK işbirliği ile Milli Eğitimi Geliştirme Projesi kapsamında (YÖK, 2007) yapılan bir düzenleme ile EPÖ alanının diğer eğitim bilimleri alanları (Psikolojik Danışma ve Rehberlik alanı dışında) gibi yalnızca lisansüstü düzeyde eğitim vermesi söz konusu olmuştur. Halen yalnızca lisansüstü düzeyde varlığııı sürdüren EPÖ alanının önemi ve gerekliliği her geçen gün eğitim alanında yaşanan hızlı değişimlerle daha da belirginleşmektedir.

Yurt dişında bu konudaki çalışmalar incelendiğinde, özellikle ABD'deki çalışmalar dikkat çekmektedir. ABD'de Rosales (1994) tarafından eğitim programları alanında öncü 25 üniversitenin lisansüstü programları ve doktora düzeyindeki çalışmaları incelenmiştir. Bu çalışmada incelenen üniversitelerin tanımlanan en tipik özellikleri, fakültelerinin gücü ve araştırmaya yönelik olmaları şeklinde ortaya çıkmıştır. Doktora çalışmaları bu kurumlar için çok önemli bulunmuştur. Yine incelenen üniversitelerin ulusal ve uluslar arası düzeyde tanınması, fakültenin saygınlığı, doktora derecesi vermesi, mezunların işe yerleştirilmesi, üstün kütüphane ve bilgisayar hizmetleri, öğrenci seçimi ve kaydı, kampuste yaşam kalitesiyle ilgili olarak eğitim programı ve ortamı diğer tipik özellikleri olmuştur. Bu okullarda sunulan tüm derslerin, özellikle araştırma derslerinin, yarar sağlaması, sosyal sorumluluk geliştirmesi, içeriğindeki bilginin felsefi değerinin olması, bireyin yaşamını zenginleştirmesi gibi ölçütleri karşılamasının beklendiği ortaya konmuştur. Araştırma sonuçları lisansüstü programların eğitim araştırmalarına odaklandığını ve bu tür programların öğrenciler tarafından tercih edildiğini göstermiştir.

Yine ABD'de yapılan bir başka araştırmada (Drake, 2011) karşılaştırmalı ve uluslar arası lisansüstü programa sahip 35 üniversite ya da merkezlere ulaşılmıştır. $\mathrm{Bu}$ programlar kapsamları, benzerlikleri, benimsedikleri felsefe ve yöntembilim açısından karşılaştırılmıştır. Söz konusu programların küreselleşme ve gelişim temalarını vurgulayarak günümüz ekonomisinde benzerlik gösterdikleri, içeriklerinde eğitim politikasının anahtar öğe olmasına karşın bu programlarda ne kazandırılması gerektiği konusunda görüş birliğine varılamadığı belirlenmiştir. Ayrıca her 
programda farklı yöntembilim ve kuramsal eğilimlerin izlendiği ortaya konmuştur.

Türkiye'de EPÖ lisansüstü eğitim programlarının temel yapısında yıllar itibariyle önemli bir değişimin yaşanmadığı, verilen dersler, alınması gereken kredi sayıları, başarı ölçütleri, öğrenci niteliği, öğretim üyesi nitelik ve niceliği ile ilgili çeşitli sorunların yaşandığı dile getirilmektedir. Gözütok, Alkın ve Ulubey'in (2010) yaptığ 1 bir araştırmada, EPÖ bölümlerindeki öğretim üyelerinin çoğunluğunun, özellikle yüksek lisans öğrencilerini "eğitim bilimleri altyapısı" açısından yetersiz olarak değerlendirdiği, Üniversitelerarası Kurul Yabancı Dil Sınavı (ÜDS)/Kamu Personeli Yabancı Dil Bilgisi Seviye Tespit Sinavi (KPDS) ve Akademik Personel ve Lisansüstü Eğitimi Giriş Sınavı (ALES) puan ölçütlerini, öğrencilerin lisansüstü programlara seçilmesinde eşit koşulların işe koşulmasını engellemesi gerekçesiyle, eleştirdiği ortaya çıkmıştır.

Karaman ve Bakırcı da (2010), Türkiye' deki en üst eğitim ve araştırma kurumu olan üniversitelerde yapılan lisansüstü programlarda öğretim üyesi sorunu, mali sorunlar, kütüphane hizmet sorunları, yabancı dil sorunu, yönetsel sorunlar, tez danışmanıyla ilgili sorunlar, araç gereç sorunları vb. sorunlar bulunduğunu belirtmişlerdir. Ayrıca yaşanan bu sorunların lisansüstü programlarda eğitim gören öğrencilerin ürettiği tezlerde, ilgili içerik ve yöntem sorunlarını da beraberinde getirebildiği ifade edilmiştir.

Belirtilen bu ve benzeri sorunlardan yola çıkarak Türkiye'de EPÖ alanında lisansüstü eğitim programlarına yönelik zaman zaman eleştiri ve öneriler getirilmektedir. Lisansüstü eğitimde temel amaç bilginin üretilmesi, kullanılması, eleştirilmesi ve üretken bir düşünce tarzıyla problem çözebilecek bireylerin yetiştirilmesi olduğundan bu konu üzerinde önemle durulmalıdır. Lisansüstü eğitimin işlevleri Arıcı (2001) tarafından bilim ve sanat üretmek, yaymak, toplumsal sorunları doğru algılamak, sorunlara çözüm önerileri geliştirmek ve üst düzey insan gücünün yetiştirilmesine katkıda bulunmak şeklinde ifade edilmiştir. Bu işlevler göz önüne alındığında lisansüstü eğitimin önemi günümüzde giderek artmaktadır. Yine lisansüstü eğitim, bir ülkenin geleceğinde söz sahibi olacak bilim adamları ve akademisyenlerin yetiştirilmesi açısından oldukça önemli bir süreçtir.

$\mathrm{Bu}$ araştırma, EPÖ ya da eğitimde program geliştirme alanında Türkiye'de ve yurt dışındaki mevcut lisansüstü eğitim programlarını belirli ölçütlere göre analiz etmek amaciyla gerçekleştirilmiştir. Buradan yola çıkarak EPÖ alanındaki lisansüstü programların çeşitli öğeleri için durum tespiti yapılıp, önerilerin geliştirilmesi düşünülmüştür. Araştırmada bu amaçla aşağıdaki sorulara yanıt aranmıştır: 
1. Türkiye'de EPÖ alanında yürütülen yüksek lisans ve doktora programlarının;

a) başvuru koşulları,

b) öğrenci kabulü,

c) zorunlu ve seçmeli dersleri,

d) mezuniyet için gerekli koşulları,

e) tez süreci nasıldır?

2. "US Top Universities" in 2010 y1lı verilerine göre dünyada ilk 100'e giren ve EPÖ ya da bu programa benzeyen programı olan üniversitelerde yürütülen yüksek lisans ve doktora programlarının;
a) başvuru koşulları,
b) mezuniyet için gerekli koşulları,
c) öne çıkan özellikleri nelerdir?

Ayrıca bu araştırma;

1. Türkiye'de yalnızca EPÖ/Program Geliştirme ile ilgili lisansüstü programları olan ve resmi dokümanlarına ulaşılabilen üniversitelerle;

2. Lisansüstü programların incelendiği yabancı üniversitelerin belirlenmesinde ise, "US Top Universities" in 2010 y1lı verileri ile EPÖ ya da bu programa benzeyen programı olan üniversitelerle sınırlandırılmışıtır.

\section{YÖNTEM}

EPÖ alanında Türkiye'de ve yurt dişındaki lisansüstü eğitim programlarını belirli ölçütlere göre analiz etmek amacıyla gerçekleştirilen bu araştırma betimsel niteliği olan bir araştırmadır.

$\mathrm{Bu}$ araştırmada; olgu veya olgular hakkında bilgi içeren ve yazılı materyallerin analizini kapsayan nitel araştırma yöntemlerinden "doküman inceleme" (Yıldırım ve Şimşek, 2008) yöntemi kullanılmışır. Doküman inceleme yönteminin kullanıldığı araştırmada; sırasıyla dokümanların belirlenmesi, belirlenen (ulaşılan) dokümanların orijinalliğinin kontrol edilmesi, verilerin analiz edilmesi ve elde edilen verilerden yola çıkarak sonuçların raporlaştırılması aşamaları izlenmiştir. Buna göre, yurt dışında söz konusu alanlardaki lisansüstü eğitim programları ile Türkiye'deki lisansüstü eğitim programlarına ilişkin basılı kaynaklar ve internet aracılığıyla elde edilenler veri kaynağı olarak kullanılmıştır. İnternet kaynağı olarak üniversitelerin resmi siteleri incelenmiştir. 


\section{Veri Kaynakları}

$\mathrm{Bu}$ araştırma için Türkiye'deki devlet üniversitelerinin tamamı incelenmiş ve 64 devlet üniversitesi içinde EPÖ alanında yüksek lisans programı olan 30 ve doktora programı olan 16 üniversite belirlenmiştir. Ancak, bu araştırmada EPÖ yüksek lisans programlarından 27'sine, doktora programlarının ise 13'üne ulaşılabilmiştir. Yurt dışındaki EPÖ lisansüstü eğitim programları belirlenirken ise, 2010 yılında "US Top Universities" tarafından belirlenen ilk 100 üniversiteden bu programa benzeyen bir lisansüstü eğitimi olan üniversiteler inceleme kapsamına alınmıştır (U.S. News \& World Report, 2010). Bu ölçüte göre, tamamı ABD ve Kanada' da olan toplam 11 lisansüstü program analiz kapsamına alınmıştır. Yüksek lisans ve doktora düzeyinde EPÖ alanındaki lisansüstü programlara, Curriculum Studies, Curriculum, Teaching and Learning, Curriculum and Instruction, Curriculum and Pedagogy, Curriculum Studies and Teacher Education, Curriculum and Teaching ve Educational Studies gibi farkl isimler verildiği görülmektedir. Tablo 1'de analiz kapsamına alınan Türkiye'de ve yurt dişında EPÖ lisansüstü programlarının bulunduğu üniversiteler verilmiştir.

Tablo 1. Türkiye'de ve yurt dışında EPÖ lisansüstü programları incelenen üniversiteler

\begin{tabular}{|c|c|c|}
\hline \multicolumn{2}{|c|}{$\begin{array}{l}\text { Türkiye'de EPÖ Lisansüstü Programları } \\
\text { İncelenen Üniversiteler }\end{array}$} & \multirow{2}{*}{$\begin{array}{l}\begin{array}{l}\text { Yurt Dışında EPÖ Lisansüstü } \\
\text { Programları İncelenen Üniversiteler }\end{array} \\
\text { Columbia University (YL-DR) }\end{array}$} \\
\hline $\begin{array}{l}\text { Abant İzzet Baysal (YL- } \\
\text { DR) }\end{array}$ & Hacettepe (YL-DR) & \\
\hline Adnan Menderes (YL-DR) & Kafkas (YL) & Stanford University (YL- DR) \\
\hline Ahi Evran (YL) & Kırıkkale (YL) & Toronto University (YL-DR) \\
\hline Akdeniz (YL) & Mehmet Akif (YL) & British Columbia University (YL- DR) \\
\hline Anadolu (YL-DR) & Mersin (YL-DR) & Boston University (YL-DR) \\
\hline Ankara (YL-DR) & Muğla (YL) & $\begin{array}{l}\text { University of Wisconsin-Madison (YL- } \\
\text { DR) }\end{array}$ \\
\hline Boğaziçi (YL) & Niğde (YL) & Illinois University (Chicago) (YL-DR) \\
\hline Çanakkale 18 Mart (YL) & ODTÜ (YL-DR) & $\begin{array}{l}\text { California University (San Diego) (YL- } \\
\text { DR) }\end{array}$ \\
\hline Çukurova (YL-DR) & Pamukkale (YL) & Texas University (Austin) (YL-DR) \\
\hline Dokuz Eylül (YL-DR) & Uludağ (YL) & Washington University (YL-DR) \\
\hline Ege (YL-DR) & Yıldız Teknik (YL-DR) & Purdue University (YL-DR) \\
\hline Erciyes (YL) & Yüzüncü Y1l (YL) & \\
\hline Firat (YL-DR) & $\begin{array}{l}\text { Zonguldak Karaelmas } \\
\text { (YL) }\end{array}$ & \\
\hline Gazi (YL-DR) & & \\
\hline
\end{tabular}




\section{Veri Toplama Yöntemi ve Analizi}

Araştırmanın amaçları doğrultusunda veri toplamak amacıyla yapılacak analizler için bir yönerge oluşturulmuştur. Oluşturulan yönerge program geliştirme alanı ve ölçme değerlendirme alanlarından 4 uzmanın görüşüne sunulmuştur. Bu yolla analiz yönergesinin hem kapsam geçerliliği hem de bilimsel uygunluğu konusunda görüşler alınmıştır. Alınan görüşler doğrultusunda aşağıda verilen analiz yönergesi kullanılmıştır.

1. Başvuru koşullart: Yabanc1 dil koşulu, yabancı dil puanı, genel yetenek sınav puanı (ALES/GRE/GMAT), lisans/yüksek lisans mezuniyet ortalaması, diğer belgeler (referans mektubu, niyet mektubu, yüksek lisansta hazırlanan proje, makale vb.)

2. Öğrenci kabulü: Öğrenci kabulünde yararlanılan sınavlar, öğrenci kabul şartları (bilimsel hazırlık, özel öğrenci, yatay geçiş koşulları)

3. Zorunlu ve seçmeli dersler: EPÖ yüksek lisans ve doktora programlarında yer alan zorunlu ve seçmeli dersler

\section{Programları tamamlama süreleri ve başarı koşulları}

5. Mezuniyet için gerekli koşullar

6. Tez süreci

$\mathrm{Bu}$ yönergede yer alan bazı maddeler (genel yetenek sinav puanı, yabancı dil puanı gibi) bazı yurt dışı üniversitelerinin ilgili internet sitesinde bulunamadığından analiz edilememiştir. Elde edilen tüm verilerde analiz birimi olarak yukarıda belirtilen sorulara ilişkin cümle ve paragraflar kullanılmıştır.

Veriler analiz edilirken araştırmacılar verilerin bulunduğu dokümanları paylaşarak ayrı ayrı analizleri gerçekleştirmişlerdir. Daha sonra araştırmacılar çalıştıkları dokümanları değiştirerek tekrar analizi gerçekleştirmişler ve araştırmacılar arasındaki tutarlı̆̆a bakılmıştır. Bunun için; ortak kodların sayısı / ortak kodların sayısı + farklı kodların sayısı formülü (Miles \& Huberman, 1984) kullanılmış, güvenirlik \%90'ın üzerinde bulunmuştur.

\section{BULGULAR}

Araştırmada elde edilen bulgular, iki ana başlık altında sunulmuştur. Birinci başlık altında Türkiye'de EPÖ alanında lisansüstü programları ile ilgili elde edilen veriler, ikinci başlık altında ise yurtdışında ilk 100'e giren üniversiteler arasında EPÖ alanında programları olan üniversitelerden elde edilen bulgular verilmiştir. 


\section{Türkiye'deki EPÖ Alanında Yürütülen Lisansüstü Eğitim Programlarına İlişkin Bulgular}

Türkiye'de EPÖ lisansüstü eğitim programları; başvuru koşulları, öğrenci kabulü ve eğitim programları bakımından incelenmiştir.

\section{EPÖ Yüksek Lisans ve Doktora Programlarına Başvuru Koşulları}

Yabancı dil koşulu

Tablo 2'de EPÖ yüksek lisans ve doktora programlarına başvuruda yabancı dil koşuluna ilişkin bulgular verilmiştir.

Tablo 2. EPÖ yüksek lisans ve doktora programlarına başvuruda istenen yabancı

\begin{tabular}{lcc}
\multicolumn{1}{c}{ dil koşulu } & & \\
\hline Yabancı Dil Koşulu & $\begin{array}{c}\text { Yüksek Lisans } \\
\text { f }\end{array}$ & $\begin{array}{c}\text { Doktora } \\
\text { f }\end{array}$ \\
\hline $\begin{array}{l}\text { Yabancı dil ile ilgili başvuru ve kabul şartı } \\
\text { belirtmeyen enstitüler }\end{array}$ & 1 & - \\
$\begin{array}{l}\text { Yabancı dili başvuruda ön koşul olan ve kabul } \\
\text { puanına eklemeyen enstitüler }\end{array}$ & 12 & 9 \\
$\begin{array}{l}\text { Yabanc1 dili başvuruda ön koşul olmayan ve kabul } \\
\text { puanına ekleyn enstitüler }\end{array}$ & 6 & - \\
$\begin{array}{l}\text { Yabancı dil puanını kabul puanına eklemeyen ve } \\
\text { başvuru puanını senato kararına bağlayan } \\
\text { enstitüler }\end{array}$ & 5 & 1 \\
$\begin{array}{l}\text { Yabancı dil koşulunu senato kararına bağlayan } \\
\text { enstitüler }\end{array}$ & 2 & 1 \\
$\begin{array}{l}\text { Yabancı dil başvuru puanı senato kararına bağlı } \\
\text { olan ve yabancı dili kabul puanına ekleyen } \\
\text { enstitüler }\end{array}$ & 1 & - \\
$\begin{array}{l}\text { Yabanc1 dil için hem başvuru puanını hem de } \\
\text { kabul şartını belirten enstitüler }\end{array}$ & - & 2 \\
\hline
\end{tabular}

Tablo 2'ye göre, Türkiye'de EPÖ yüksek lisans programı incelenen 27 enstitüden 12'si EPÖ yüksek lisans programına başvuruda, doktora programı incelenen 13 enstitüden 9'u EPÖ doktora programına başvuruda yabancı dil koşulunu ön koşul olarak belirtmiş, ancak toplamda başvuru için hesaplanan puana yabancı dil puanının etkisini yansıtmamışlardır. Bunun ardından 6 enstitü EPÖ yüksek lisans programına başvuruda yabancı dili ön koşul olarak belirtmemiş, fakat başvuru için hesaplanan toplam kabul puanına eklemiştir. Bunun dışında, sadece 1 enstitü (Yüzüncü Yıl Üniversitesi) yabancı dili başvuru ve kabulde ön koşul olarak belirtmemiştir. Doktora programı için ise böyle bir durum söz konusu değildir. 
Yabancı dil puanı

Tablo 3'te EPÖ yüksek lisans ve doktora programlarına başvuru için gerekli olan yabancı dil puanına ilişkin bulgular verilmiştir.

Tablo 3. EPÖ yüksek lisans ve doktora programlarına başvuru için gerekli olan yabancı dil puanı

\begin{tabular}{lcc}
\hline Yabancı Dil Puanı & Yüksek Lisans & $\begin{array}{c}\text { Doktora } \\
\text { f }\end{array}$ \\
\hline Yabancı dil puanını 40 olarak belirleyen enstitüler & 2 & - \\
Yabancı dil puanını 50 olarak belirleyen enstitüler & 6 & - \\
Yabancı dil puanını 55 olarak belirleyen enstitüler & 1 & 7 \\
Yabancı dil puanını 60 olarak belirleyen enstitüler & 1 & 3 \\
Yabancı dil puanını 65 olarak belirleyen enstitüler & 1 & 1 \\
Yabancı dil puanını 70 olarak belirleyen enstitüler & 1 & - \\
Yabancı dil puanını senatonun belirlediği puan olarak & 13 & 2 \\
kabul eden enstitüler & 2 & - \\
Yabancı dil puanını belirtmeyen enstitüler & & \\
\hline
\end{tabular}

İncelenen 27 enstitüden 13'ü EPÖ yüksek lisans programına başvuruda yabancı dil puanı olarak üniversite senatosunun belirlediği puanı kabul ettiğini, doktora programı için incelenen 13 enstitüden 7'si EPÖ doktora programına başvuruda yabancı dil puanı olarak en az 55 puanı kabul ettiğini belirtmiştir. Ayrıca, incelenen enstitüler arasında 2 enstitü (Adnan Menderes Üniversitesi, Muğla Üniversitesi), EPÖ yüksek lisans programına başvuruda en düşük yabancı dil puanı olarak 40 puanı, 1 enstitü de (Dokuz Eylül Üniversitesi) en yüksek yabanc1 dil puanı olarak 70 puanı istemektedir. Ayrıca EPÖ doktora programına başvuruda, incelenen enstitüler arasında en yüksek yabancı dil puanını (65 puan) 1 enstitü (ODTÜ) istemektedir. Bunun dışında 2 enstitü de EPÖ yüksek lisans programına başvuruda herhangi bir yabancı dil puanını ön koşul olarak belirtmemiştir. Yabancı dil puanının belirlenmesini senatoya bırakan enstitüler, senato kararına göre dil puanını Tablo 3'te belirtilen puanlardan daha yüksek tutabilmektedir. Ancak enstitülerin yönetmeliklerinde belirtilenler bulgulara yansitılmaya çalışılmıştır.

\section{Genel yetenek sinav puanı (ALES/GRE/GMAT)}

Tablo 4'te EPÖ yüksek lisans ve doktora programlarına başvuruda ALES puanına ilişkin bulgular verilmiştir. 
Tablo 4. EPÖ yüksek lisans ve doktora programlarına başvuruda gerekli olan ALES puani

\begin{tabular}{lcc}
\hline ALES Puanı & $\begin{array}{c}\text { Yüksek Lisans } \\
\text { f }\end{array}$ & $\begin{array}{c}\text { Doktora } \\
\text { f }\end{array}$ \\
\hline 45 puanı alt sınır olarak kabul eden enstitüler & 3 & 1 \\
50 puanı alt sınır olarak kabul eden enstitüler & - & 2 \\
55 puan1 alt sınır olarak kabul eden enstitüler & 21 & 8 \\
60 puan1 alt sınır olarak kabul eden enstitüler & - & 2 \\
65 puanı alt sınır olarak kabul eden enstitüler & 1 & - \\
Senato tarafindan belirlenir. & 2 & - \\
\hline
\end{tabular}

Tablo 4'e göre, incelenen 27 enstitüden 21'i EPÖ yüksek lisans programına, 13 enstitüden 8'i ise doktora programına başvuruda en az 55 ALES puanını ön koşul olarak belirlemiştir. Yüksek lisans programı için en yüksek ALES puanını (65 puan) ön koşul olarak belirten bir enstitü (Dokuz Eylül Üniversitesi) olmuştur. Doktora programı için ise en yüksek ALES puanını (60 puan) ön koşul olarak belirten iki enstitü (Dokuz Eylül Üniversitesi, Gazi Üniversitesi) olmuştur. İncelenen enstitülerde en düşük ALES puanını (45 puan) ise yüksek lisans programı için 3 (Çukurova Üniversitesi, Hacettepe Üniversitesi, ODTÜ), doktora programı için 1 enstitü (Çukurova Üniversitesi) belirtmiştir.

Lisans/Yüksek Lisans mezuniyet ortalamast

Tablo 5'te, yüksek lisans ve doktora programlarına başvuruda enstitüler tarafından belirtilen lisans ve/veya yüksek lisans mezuniyet ortalamalarına yer verilmiştir.

Tablo 5. EPÖ yüksek lisans ve doktora programlarına başvuruda gerekli olan lisans/yüksek lisans mezuniyet ortalamast

\begin{tabular}{lcc}
\hline Lisans/Yüksek lisans mezuniyet ortalaması & $\begin{array}{c}\text { Yüksek Lisans } \\
\text { f }\end{array}$ & $\begin{array}{c}\text { Doktora } \\
\text { f }\end{array}$ \\
\hline 100/85 (lisans derecesiyle başvuranlar için) & 1 & - \\
100/85 & - & 1 \\
100/75 (y. lisans ortalaması) & - & 1 \\
100/70 (y. lisans ortalaması) & - & 1 \\
100/60 & 1 & - \\
100/60 (lisans ortalaması), 100/80 (y. lisans & - & 1 \\
ortalamas1), 100/65 (sadece lisans derecesiyle & & \\
başvuranlar için) & - & 1 \\
4/3 (lisans derecesiyle başvuranlar için) & - & 1 \\
$4 / 3$ ya da 100/80 (y. lisans ortalamasi) & - & 1 \\
$4 / 2,7$ (y. lisans ortalaması) & 1 & - \\
$4 / 2,3$ Senato tarafindan belirlenir. & 2 & 1 \\
\hline
\end{tabular}


Tablo 5'te de görüldüğü gibi enstitülerin çok azı (yüksek lisansta 5, doktorada 8 enstitü) lisansüstü eğitim yönetmeliklerinde istenen mezuniyet ortalamalarını belirtmiştir. Mezuniyet ortalamasını belirten enstitülerden 3'üu, doktora programına lisans derecesiyle başvuracaklar için lisans mezuniyet ortalamasını da belirtmiştir. Analiz kapsamına alınan enstitülerin tamamının mezuniyet ortalamalarına ulaşılamamış olsa bile tabloda verilen bulgular bu konuda çok farklı uygulamaların varlığını gösterir niteliktedir.

Diğer belgeler (referans mektubu, yüksek lisansta hazırlanan proje, makale $v b$.)

Enstitülerin eğitim-öğretim yönetmelikleri incelediğinde, Ankara, Çanakkale 18 Mart, Çukurova ve Mehmet Akif Ersoy Üniversiteleri lisans üstui programlarına başvuruda referans mektubu istendiğini belirtmiştir.

Uludağ Üniversitesi yüksek lisans programında, Ankara ve Dokuz Eylül Üniversiteleri de doktora programında tez ile ilgili en az bir makalenin hakemli bir dergide yayımlanmak üzere kabul edilmiş olmasını mezuniyet için koşul olarak yönetmeliklerinde belirtmişlerdir.

Ayrıca, mezun olmak için koşul olarak belirtilen proje çalışmaları enstitülerin özellikle tezsiz yüksek lisans programlarında belirtilmiştir. Diğer programlar için ise sınavlar ve derslerin değerlendirilmesi ile ilgili olarak projelerin de kullanılabileceği vurgulanmıştır.

\title{
EPÖ Yüksek Lisans ve Doktora Programlarına Öğrenci Kabulü
}

\author{
Öğrenci kabul şartları (bilimsel hazırlık, özel öğrenci, yatay geçiş \\ koşulları) \\ Araştırmada ele alınan üniversiteler yüksek lisans ve doktora \\ programları için bilimsel hazırlık, özel öğrenci kabulü ve yatay geçiş ile \\ ilgili enstitü yönetmeliklerinde açıklamalara yer vermişlerdir.
}

Bilimsel hazırlık programı

İncelenen 27 enstitünün birisi bilimsel hazırlık programı şartlarını senatoya bırakırken diğerleri yönetmeliklerinde belirtmişlerdir. 26 enstitü bilimsel hazırlık programının süresini 1 takvim yılı olarak belirtmiştir. 26 enstitüden 15 'i bilimsel hazırlık programına katılan öğrencilerin bu süreçte lisansüstü programdan da ders alabileceğini yönetmeliklerinde ifade etmiştir. Bunlardan 12'si lisansüstü programından alınabilecek derslerle ilgili kredi ve/veya ders sınırını yönetmeliğinde belirtmiştir. Lisansüstü programından alınabilecek kredi sınırı ile ilgili olarak bu enstitüler, genel olarak en az 6 kredi ile en çok 24 krediye kadar ders alınabileceğini belirtmişlerdir. Ayrıca 7 enstitü ise, bilimsel hazırlık programında alınan derslerle ilgili başarı ölçütlerini yüksek lisans için 65-75 puan arasında, doktora için ise 70-75 puan arasında belirtmiştir. 


\section{Özel ögrrenci kabulü}

EPÖ lisansüstü programı olan 21 enstitüden 6's1 özel öğrencilik süresini 2 yarıyıl, 3 enstitü de 4 yarıyıl olarak belirlemiştir. Bunun dışında, 16 enstitü de özel öğrencilik için ders ve/veya kredi sınırları getirmişlerdir. Bu enstitüler, özel öğrenciler için her yarıyılda en çok 2 ders ya da en çok 18 krediye kadar ders alma koşulunu yönetmeliklerinde belirtmişlerdir.

Yatay geçişle öğrenci kabulü

EPÖ lisansüstü programı açan 24 enstitü yatay geçişle ilgili kabul şartlarını yönetmeliklerinde belirtmişlerdir. Bu enstitülerden 20'si en az bir yarıyılı başarı ile tamamlamış olan öğrencilerin ilgili anabilim dalına yatay geçişini kabul ettiklerini belirtmiştir. Yine bu 20 enstitüden 11'i başarı ile ilgili bazı ölçütler belirtmişlerdir. Genel olarak alınan derslerden beklenen not ortalamasının 60 ile 75 arasında olmasının beklendiği görülmektedir. Ayrıca enstitülerden ikisi (Hacettepe Üniversitesi, ODTÜ) yüksek lisans programından doktora programına geçişi, yine iki enstitü lisans derecesiyle doktora programına alınan öğrenciler için yükssek lisans programına geçişi yönetmeliklerinde açıklamışlardır.

\section{EPÖ Yüksek Lisans ve Doktora Eğitim Programlarında Yer Alan Zorunlu ve Seçmeli Dersler}

Bu bölümde, incelenen 27 enstitüdeki yüksek lisans ve 13 enstitüdeki doktora programlarında yer alan dersler ele alınmıştır. Yüksek lisans için 21, doktora için 13 enstitü, programlarının zorunlu ve seçmeli derslerini internet sayfalarında vermiştir. Yüksek lisans derslerinde Ahi Evran Üniversitesi, Kafkas Üniversitesi ve Kırıkkale Üniversitesi'nin enstitülerinde açılan, söz konusu programda verilen derslere ulaşılamamıştır. Niğde Üniversitesi'nde yüksek lisans dersleri zorunlu ve seçmeli ayrımı belirtilmeden sunulurken, Boğaziçi Üniversitesi ve Pamukkale Üniversitesi'nde de sadece zorunlu dersler verilmiştir. $\mathrm{Bu}$ nedenle, Boğaziçi, Niğde ve Pamukkale Üniversitelerinin lisansüstü dersleri sadece zorunlu dersler tablosunda verilmiştir. Tablo 6'da EPÖ alanında yüksek lisans düzeyinde verilen zorunlu derslere ilişkin bulgular sunulmuştur.

Tablo 6'ya göre, incelenen 21 enstitüde EPÖ yüksek lisans programlarında ortak olarak zorunlu dersler içinde en çok Bilimsel Araştırma ve İstatistik, Ö̆grenme Öğretme Süreçleri ile Ĕ̆itimde Program Geliştirme ve Ĕ̈itimde Program De ğerlendirme derslerine yer verildiği görülmektedir. $\mathrm{Bu}$ bulgu EPÖ yüksek lisans zorunlu derslerinin büyük ölçüde birbirine benzer olduğunu göstermektedir. 
Tablo 6. EPÖ yüksek lisans programlarında yer alan zorunlu dersler

\begin{tabular}{lc}
\hline Zorunlu Dersler & f \\
\hline Program Geliştirme ve Değerlendirme I, II & 2 \\
Eğitimde Program Değerlendirme & 6 \\
Eğitimde Program Geliştirme I, II & 7 \\
Öğrenme Öğretme Süreçleri/Kuram Temelleri/ Öğrenme Kuramları & \\
/Öğretim Model ve İlkeleri, Öğretim Tasarımları & 11 \\
$\begin{array}{l}\text { Eğitimde Ölçme Teknikleri } \\
\text { Uygulamalı Eğitim İstatistiği/ Eğitim İstatistiği / İstatistiksel Yöntemler }\end{array}$ & 3 \\
$\begin{array}{l}\text { ve Uygulamaları/ Bilimsel Araştırma Yöntemi ve İstatistiği } \\
\text { Bilimsel Araştırma Teknikleri/Yöntemleri//Eğitimde Araştırma Yöntem } \\
\text { ve Teknikleri/Sosyal Bilimlerde Araştırma Yöntemleri }\end{array}$ & 8 \\
\hline
\end{tabular}

Yüksek lisans programlarında yer alan seçmeli derslere ilişkin elde edilen bulgular ise aşağıda sunulmuştur.

Tablo 7. EPÖ yüksek lisans programlarında yer alan seçmeli dersler

\begin{tabular}{ll}
\hline Seçmeli Dersler & f \\
\hline Eğitimde Yeni Teknolojilerin Kullanımı/Çağdaş Öğretim Teknolojilerinin & 3 \\
Kullanımı & 6 \\
HİE Programlarının Geliştirilmesi/HİE Programları/ Yönetimi & 3 \\
Program Geliştirmede İhtiyaç Analizi/Eğitim Gereksinimlerinin & 6 \\
Saptanması & 6 \\
Program Değerlendirme & 6 \\
Karşılaştırmalı Eğitim/Karşılaştırmalı Eğitimde Araştırma & \\
Sorunları/Karşışışırmalı Eğitim Programları ve Öğretim & 7 \\
Öğretimin Düzenlenmesinde Yeni Yaklaşımlar/Öğretme-Öğrenme & 7 \\
Yaklaşımları/ Öğrenme Stratejileri/Öğretme-Öğrenme Stratejileri & 3 \\
Avrupa Eğitim Sistemleri/ Avrupa Okul Reformları & 4 \\
Etkili Sınıf Yönetimi/ Sınıf Yönetiminde Kuram ve Uygulama & 4 \\
Türk Eğitim Tarihi & 4 \\
İlköğretim ve Ortaöğretim Programları & 5 \\
Eğitim İstatistiği/Eğitimde İstatistiksel Yöntemler & 4 \\
Test ve Ölçek Geliştirme & 4 \\
Nitel Araştırma Teknikleri/Nitel Araştırma Yöntemleri ve Teknikleri & \\
\hline
\end{tabular}

Tablo 7'ye göre, incelenen 21 enstitüde EPÖ yüksek lisans programlarında ortak olarak seçmeli dersler içinde en çok Öğretme ve Öğrenme Süreçleri, HïE Programlart, Program Değerlendirme ve Karşılaştırmalı Ĕ̆itim gibi derslere yer verilmiştir. EPÖ yüksek lisans programlarında en az yer alan seçmeli dersler ise Ĕ̈itimde Yeni 
Teknolojilerin Kullanımı, Program Geliştirmede İhtiyaç Analizi, Avrupa Ĕ̆itim Sistemleri gibi dersler olmuştur.

Tablo 6 ve 7 birlikte incelendiğinde, bilimsel araştırma yöntemleri ve istatistik dersleri dışarıda bırakıldığında, EPÖ yüksek lisans programlarının genel olarak program geliştirme, program değerlendirme, öğretme ve öğrenme süreçleri, hizmet içi eğitim ve karşılaştırmalı eğitim gibi derslerden oluştuğu söylenebilir. Doktora programlarında yer alan zorunlu ve seçmeli dersler ise Tablo 8 ve 9' da sunulmuştur.

Tablo 8. EPÖ doktora programında yer alan zorunlu dersler

\begin{tabular}{ll}
\hline Zorunlu Dersler & f \\
\hline Öğrenme Öğretme Süreçleri/Kuramları & 2 \\
Program Değerlendirme/Yaklaşımları/ Program Değerlendirme: & 5 \\
Kuram ve Uygulama & 2 \\
Yükseköğretim Programlarında Yeni Yaklaşımlar & 4 \\
Program Geliştirme ve Uygulamaları/ Program Geliştirme: Kuram ve & 4 \\
Uygulama/Program Geliştirme & 2 \\
Başarı Testleri ve Ölçek Geliştirme/ Ölçek Geliştirme Teknikleri & 2 \\
\hline
\end{tabular}

Tablo 8 incelendiğinde, doktora programı incelenen 13 enstitüde EPÖ doktora programlarında zorunlu dersler içinde ortak olarak Program Değerlendirme ve Program Geliştirme dersleri ön plana çıkmaktadır. Yine ortak olarak zorunlu derslerde en az Öğrenme Öğretme Süreçleri, Başarı Testleri ve Ölçek Geliştirme ile Yükseköğretim Programlarında Yeni Yaklaşımlar gibi derslere yer verilmiştir.

Tablo 9. EPÖ doktora programında yer alan seçmeli dersler

\begin{tabular}{ll}
\hline Seçmeli Dersler & f \\
\hline Hizmet içi Eğitim Programları ve Değerlendirmesi/ Uygulama & 2 \\
Karşılaştırmalı Eğitim & 3 \\
Eğitim Felsefesi & 2 \\
Türk Eğitim Sisteminin Yapısı Sorunları/Örgüt ve Yönetim Sorunları & 4 \\
Program Geliştirme Alan Çalışması & 3 \\
İletişim Becerileri/İletişim & 2 \\
Türk Eğitim Sisteminde Yenileşme Sorunları/Sorunlar & 2 \\
İleri İstatistik & 2 \\
Program Geliştirmede Yeni Yaklaşımlar/Yönelimler & 3 \\
Program Değerlendirmede Alan Çalışmaları/Program Değerlendirme & 2 \\
Araştırması & 2 \\
Öğretmen Eğitimi ve Sorunları/Türkiye'de Öğretmen Yetiştirme Sorunu & 2 \\
Öğretme ve Öğrenme Stratejileri & 2 \\
\hline
\end{tabular}


Tablo 9 incelendiğinde ise, doktora programı incelenen 13 enstitüde, EPÖ doktora programlarında seçmeli dersler içinde en çok Türk Eğitim Sisteminin Yapısı Sorunları/Örgüt ve Yönetim Sorunları, Karşılaştırmalı Ĕgitim, Program Geliştirmede Yeni Yaklaşımlar gibi derslere yer verilmiştir. En az ise Hizmet içi Ĕ̆itim Programları ve Değerlendirmesi, Eğitim Felsefesi, Illeri İstatistik, Öğretmen Eğitimi ve Sorunlarl gibi seçmeli derslere yer verilmiştir.

Tablo 8 ve 9 birlikte incelendiğinde, EPÖ doktora programında verilen derslerin yüksek lisans dersleri ile oldukça benzer olduğu söylenebilir. Ancak bu benzerlik daha çok EPÖ alan derslerinde görülmektedir. Diğer taraftan, bilimsel araştırma ve istatistik gibi derslere EPÖ doktora programlarında yeterince yer verilmediği dikkat çekmektedir (Ders programları incelendikten sonra sadece bir enstitüde belirlenen dersler tabloda gösterilmemiştir). Bu durumun temel nedeni, öğrencilerin bu tür dersleri diğer anabilim dallarının programlarından alma olanağına sahip olmalarıdır. Bu nedenle, bu dersler EPÖ lisansüstü eğitim programlarının dersleri arasında gösterilememiş olabilir.

\section{EPÖ Yüksek Lisans ve Doktora Eğitim Programlarını Tamamlama Süreleri ve Başarı Koşulları}

Programı tamamlama süreleri

Araştırmada incelenen 27 enstitü, EPÖ yüksek lisans programında dersler ve tezin tamamlanması için 4 yarıyıl süre tanımıştır. Gerekli durumlar için 2 yarıyıl ek süre de verilmiştir. Ancak, doktora programını tamamlama süresi üniversitelere göre bazı farklılıklar göstermektedir. Tablo 10 'da doktora programını tamamlama süresine ilişkin bulgular verilmiştir.

Tablo 10. EPÖ doktora programını tamamlama süresi

\begin{tabular}{lc}
\hline Doktora Programını Tamamlama Süresi & $\begin{array}{c}\text { Enstitü sayısı } \\
\text { f }\end{array}$ \\
\hline YL + 7 yy-8 yy; L+9 yy-10 yy & 1 \\
8 yy + 4 yy ek süre & 5 \\
YL+ 6yy-8yy + 4yy ek süre; L+ 8yy-10yy & 7 \\
\hline
\end{tabular}

Tablo 10'a göre, EPÖ doktora programı olan enstitüler yüksek lisans mezunlarına 8 yarıyıla kadar süre tanımakta ve gerekli durumlarda 4 yarıyıl ek süre vermekte, lisans mezunlarına ise 10 yarıyıla kadar doktora programını tamamlamaları için süre tanımaktadır. 
Başarı koşulları

Tablo 11'de, EPÖ yüksek lisans ve doktora programları için başarı koşulları verilmiştir. Bu koşullar ders geçme notları ve sınav türleri ile ilgilidir.

Tablo 11. EPÖ yüksek lisans ve doktora programlarında geçme notu

\begin{tabular}{lcc}
\hline Geçme Notu & $\begin{array}{c}\text { Yüksek Lisans } \\
\text { f }\end{array}$ & $\begin{array}{c}\text { Doktora } \\
\text { f }\end{array}$ \\
\hline Ders geçme notunu 75 puan olarak belirleyen enstitüler & 1 & 9 \\
Ders geçme notunu 70 puan olarak belirleyen enstitüler & 14 & 1 \\
Ders geçme notunu 65 puan olarak belirleyen enstitüler & 4 & - \\
$\begin{array}{l}\text { Ders geçme notunu 4/2+ genel ortalamay1 4/2,7 olarak } \\
\text { belirleyen enstitüler }\end{array}$ & 1 & - \\
$\begin{array}{l}\text { Ders geçme notunu 4/2,7+ genel ortalamayı 4/3 olarak } \\
\text { belirleyen enstitüler }\end{array}$ & - & 1 \\
Ders geçme notunu BB puan olarak belirleyen enstitüler & - & 1 \\
Ders geçme notunu CB puan olarak belirleyen enstitüler & 1 & - \\
\hline
\end{tabular}

İncelenen 27 enstitüden 21'i yüksek lisans programları için geçme notunu belirtmiştir. Bunlardan 14'ü yüksek lisans programları için 70 puan olarak ders geçme notunu belirtirken, 4'ü her bir dersten geçme notunu 65 olarak belirlemiştir. Yüksek lisans programında ders geçme notu olarak en yüksek puanı 1 enstitü (Dokuz Eylül Üniversitesi) 75 puan olarak belirtmiş̧tir. Doktora programı için ise, incelenen 13 enstitüden 12'si geçme notunu belirtmiş̧ir. Bunlardan 9 enstitï ders geçme notunu 75 puan olarak yönetmeliğinde vermiştir. İncelenen enstitüler arasında bu geçme notu aynı zamanda en yüksek geçme notudur (Anadolu Üniversitesi, Ankara Üniversitesi, Dokuz Eylül Üniversitesi, Ege Üniversitesi vb.).

Ayrıca EPÖ yüksek lisans programları için 27 enstitüden 10'u ve doktora programları için ise 13 enstitüden 6's1 uygulanabilecek sınav türlerini açıklamıştır. Bu enstitülerin çoğunlukla yazılı, sözlü ve uygulamalı çalışmalarla sınavların yapılabileceğini belirttikleri görülmektedir.

\section{EPÖ Yüksek Lisans ve Doktora Programlarından Mezuniyet İçin Gerekli Koşullar}

Bu bölümde, EPÖ yüksek lisans ve doktora programlarından mezuniyet için gerekli olan koşullara yer verilmiştir. 
Tablo 12. EPÖ lisansüstü eğitim programlarında yüksek lisans mezuniyeti için gerekli koşullar

\begin{tabular}{lc}
\hline Mezuniyet Koşulları & $\begin{array}{c}\text { Enstitü sayısı } \\
\text { f }\end{array}$ \\
\hline 7 ders +1 seminer + tez $=$ en az 21 kredi & 21 \\
8 ders +1 seminer + tez $=24$ kredi & 3 \\
12 seçmeli/zorunlu ders +1 seminer + tez $=$ en az 24 kredi & 1 \\
Her dönem 1 seçmeli ders +1 İngilizce ders +1 seminer + tez $=30$ kredi & 1 \\
7 ders +1 seminer + tez $=21-28$ kredi & 1 \\
\hline
\end{tabular}

Tablo 12'ye göre, enstitülerin çoğu (21) EPÖ yüksek lisans programından mezuniyet için 7 ders, seminer, tez çalışması ile 21 krediyi tamamlamayı zorunlu tutmuş̧ur. Bunun ardından en çok 24 krediyi mezuniyet için zorunlu sayan 4 enstitü belirlenmiştir. 1 enstitü (Dokuz Eylül Üniversitesi) ise mezuniyet için en fazla krediyi (30) almayı koşul olarak belirtmiştir.

Tablo 13. EPÖ lisansüstü eğitim programlarında doktora mezuniyeti için gerekli koșullar

\begin{tabular}{|c|c|}
\hline Koşullar & $\begin{array}{c}\text { Enstitü sayısı } \\
\text { f }\end{array}$ \\
\hline YL +7 ders + seminer + yeterlik sınav $1+$ tez + makale $=21$ kredi & \\
\hline $\mathrm{L}+2$ seminer + yeterlik sinav $1+$ tez + makale $=42$ kredi & 5 \\
\hline 7 ders +2 seminer + yeterlik sinav $1+$ tez $=21$ kredi & 2 \\
\hline 7 zorunlu ders +2 seçmeli ders $=27$ kredi & 1 \\
\hline $\mathrm{YL}+8$ ders +2 seminer + yeterlik sinav $1+$ tez $=24-36$ kredi & \\
\hline $\mathrm{L}+14$ ders + yeterlik sinav $1+$ tez $=42-48 \mathrm{kredi}$ & 1 \\
\hline 7 ders +2 seminer + yeterlik sinav $1+$ tez + makale $=21$ kredi & 1 \\
\hline 1 İngilizce ders +2 . gruptan $3 \mathrm{kredi}+3$. gruptan $18 \mathrm{kredi}=21-24 \mathrm{kredi}$ & 1 \\
\hline 7 ders +1 seminer + yeterlik sinav $1+$ tez $=21 \mathrm{kredi}$ & 1 \\
\hline 8 ders +1 seminer + yeterlik sınav $1+$ tez çalışmas $1=24-30$ kredi & 1 \\
\hline
\end{tabular}

Tablo 13 incelendiğinde, 9 enstitü doktora programından mezuniyet için; 7 ders, seminer, yeterlik sınavı, tez ve/veya makale çalışmasıyla 21 krediyi tamamlamayı zorunlu tutmuştur. Bunun dışında 1 enstitü ise (Adnan Menderes Üniversitesi) 8 ders, 2 seminer, yeterlik sınavı ve tez çalışması ile 24-36 krediyi mezuniyet için tamamlamayı zorunlu tutarak en fazla krediyi belirtmiştir. Ayrıca 2 enstitü de (Hacettepe Üniversitesi, Yıldız Teknik Üniversitesi) lisans mezunu olup doktora programında olanlar için 42 ila 48 krediyi mezuniyette tamamlama koşulunu belirtmiştir. Doktora mezuniyeti için gerekli olacak kredi sayılarının yüksek lisans üzerine en az 21 en fazla 30 kredi olarak belirlendiği de dikkat çekmektedir. 


\section{EPÖ Lisansüstü Eğitim Programlarında Tez Süreci}

EPÖ Yüksek Lisans Programlarında Tez Süreci

Bulguların bu bölümünde, enstitülerin EPÖ yüksek lisans tez süreci ve tezin sonuçlanmasına ilişkin yönetmeliklerinde yer alan açıklamaları özetlenmiştir.

Tez süreci: 25 enstitü yüksek lisans tezi sürecine ilişkin açıklamalara yönetmeliğinde yer vermiştir. Tez süreci ile ilgili olarak tez danışmanlarının öğretim üyeleri ya da doktoralı öğretim görevlileri arasından seçilebileceği belirtilmiştir.

Tezin sonuçlanması: 26 enstitü yüksek lisans tezinin sonuçlanmasına ilişkin açıklamalara yönetmeliğinde yer vermiştir. Enstitüler yönetmeliklerinde bu bölümle ilgili olarak tez jürisinin oluşturulması ve jürinin kararına ilişkin açıklamalarda bulunmuştur. Buna göre tez jürisinin; tez danışmanından, en az birinin ilgili anabilim dalından/Enstitui içindeki başka bir anabilim dalından öğretim üyesi veya başka bir yükseköğretim kurumundan alanla ilgili olmak üzere 3 öğretim üyesinden oluştuğu, 2. tez danışmanının jüri üyesi olması halinde jürinin 5 kişiden oluşabileceği, biri ilgili anabilim dalından, diğeri başka bir anabilim dalından veya başka bir yükseköğretim kurumundan alanla ilgili olmak üzere 2 yedek üye belirlenebileceği açıklanmıştır. Ayrıca enstitülerin tümünün yönetmeliğinde jürinin tez hakkında kabul, ret veya düzeltme kararı verdiği, düzeltme kararı verilen öğrencinin en geç 3 ay içinde düzeltmelerini yaparak tezini savunması gerektiği, bu savunma sonunda da tezi reddedilen öğrencinin kaydının silineceği belirtilmiştir.

\section{EPÖ Doktora Programlarında Yeterlik Sinavi ve Tez Süreci}

$\mathrm{Bu}$ bölümde de, enstitülerin EPÖ doktora programlarındaki yeterlik sınavı, tez önerisi savunması, tez izleme komitesi, tez süreci ve tezin sonuçlanmasına ilişkin yönetmeliklerinde yer alan açıklamaları özetlenmiştir.

Yeterlik sınavı: 12 enstitü doktora yeterlik sınavına ilişkin açıklamalara yönetmeliğinde yer vermiştir. Tüm enstitüler yönetmeliklerinde doktora yeterlik komitesinin 5 öğretim üyesinden oluştuğunu, sınavın yazılı ve sözlü iki bölüm halinde yapıldığını, yeterlik sınavında başarısız olan öğrencinin bir sonraki yarıyılda tekrar sınava girdiğini, bu sınavda da başarısız olursa enstitü ile ilişiğinin kesileceğini belirtmiş̧tir. $\mathrm{Bu}$ açıklamaları yapan enstitülerden biri (Ege Üniversitesi) yazılıdan 100/75, sözlüden 100/75 puan alma koşulunu belirtmiştir. Bunun dışında yeterlik sınavına giriş ile ilgili olarak, 6 enstitü doktora programındaki öğrencilerin 4 (1 enstitü) ya da 5. yarıyılın sonuna kadar yeterlik sınavına girmelerini zorunlu tutarken, yine bu 
12 enstitüden 6'sı yeterlik sınavına girmek için yabancı dil koşulunu belirtmiştir.

Tez önerisi savunması: 12 enstitü doktora tez önerisi savunmasına ilişkin açılamalara yönetmeliğinde yer vermiştir. Enstitüler yönetmeliklerinde, doktora yeterlik sınavında başarılı olan öğrencinin en çok 6 ay içinde tez önerisini Tez İzleme Komitesi (TİK)'ne sözlü olarak sunacağını, tez önerisinin kabul veya reddine karar verileceğini, tez önerisi reddedilen öğrencinin yeni bir konu ve danışman seçebileceğini belirtmiştir. Ayrıca öğrencinin, danışman değiştirmediyse 3 ay içinde, değiştirdiyse 6 ay içinde önerisini sunması gerektiği, tez önerisi kabul edilen öğrenci için TİK' in yılda iki defa toplandığı, TİK tarafından üst üste iki kez veya aralıklı olarak üç kez başarısız bulunan öğrencinin Enstitü ile ilişiğinin kesileceği belirtilmiştir.

Tez izleme komitesi: 12 enstitü Tez İzleme Komitesi'ne ilişkin açıklamalara yönetmeliğinde yer vermiştir. Bu enstitülerin yönetmeliklerinde yeterlik sınavında başarılı olan öğrenci için oluşturulan Tez İzleme Komitesi'nin 3 üyeden oluştuğu, komitede tez danışmanından başka ilgili enstitü anabilim dalı içinden ve dışından birer üyenin yer aldığı belirtilmiştir. $\mathrm{Bu}$ enstitülerden biri (Gazi Üniversitesi) Tez İzleme Komitesi ile ilgili açıklamalara ek olarak, Tez İzleme Komitesi'nde 2 yedek üyenin de yer aldığını, komitenin 3 yıl süreyle görev yaptığını, ikinci tez danışmanının, dilediği takdirde Tez İzleme Komitesi toplantılarına katılabileceğini, ancak oy kullanamayacağını yönetmeliğinde belirtmiştir.

Tez süreci: 12 enstitü yönetmeliğinde doktora tez sürecine ilişkin açıklamaya yer vermiştir. Tez süreci açıklamalarında tez danışmanının atanmasına ilişkin ilkeler ortaya konmuştur. Enstitülerin çoğunluğu (9) tez danışmanının öğretim üyeleri arasından seçilip atanabileceğini, 2 enstitü ise tez danışmanının sadece profesör veya doçent unvanlı öğretim üyelerinden seçilip atanabileceğini belirtmiştir. Bir enstitü de atanacak tez danışmanının niteliklerinin senato tarafından belirlendiğini yönetmeliğinde açıklamıştır.

Tezin sonuçlanmast: 12 enstitünün doktora tezinin sonuçlanması ile ilgili açıklamalara yönetmeliğinde yer verdiği görülmektedir. Bütün enstitüler tez jürisinin; 3'ü TİK'den, en az birinin başka bir yükseköğretim kurumundan olmak üzere 5 üyeden oluştuğunu, jürinin tez hakkında kabul, ret veya düzeltme kararı verdiğini, düzeltme kararı verilen öğrencinin en geç 6 ay içinde düzeltmelerini yaparak tezini savunması gerektiğini, savunma sonunda tezi kabul edilmeyen öğrencinin enstitü ile ilişiğinin kesileceğini belirtmiştir.

Bir enstitü ise (Fırat Üniversitesi), öğrencilerin doktora aşamasında eğitim bilimlerine ait, Gelişim ve Öğrenme ile Öğretimde Planlama ve Değerlendirme derslerini almaları ve doktora tez savunma sinavina 
girebilmesi için de bu derslerden başarılı olmaları gerektiğini, eğer bu dersler veya eşdeğeri alınmış ise muaf sayılabileceklerini yönetmeliğinde belirtmiştir.

Yurt Dışındaki Üniversitelerde Eğitim Programları ve Öğretim Alanında Yürütülen Lisansüstü Eğitim Programlarına İlişkin Bulgular

Yurt dışındaki üniversitelerde yer alan EPÖ lisansüstü eğitim programları; başvuru koşulları, mezuniyet için gerekli kredi yükleri, öne çıkan özellikleri ve dersler bakımından incelenmiştir.

Başvuru Koşullart

Yurt dişında incelenen 11 üniversitede yüksek lisans ve doktora programlarına başvuruda aşağıdaki koşulların sağlanması beklenmektedir:

- Adayın özgeçmişi

- Niyet mektubu

- Not dökümü

- Referans/Tavsiye mektupları

- GRE puanı

- TOEFL (ikinci dili İngilizce olanlar için) puanı

- 1-2 yıl öğretmenlik deneyimi ya da alanıyla ilgili profesyonel deneyim (Bazı program isimlerinde eğitim programı ve öğretmen eğitimi bir arada geçmektedir. $\mathrm{Bu}$ tür programa sahip 3 üniversite -California, Toronto, Illinois- bu koşulu belirtmiştir). Ayrıca doktora programlarına öğrenci kabulünde yukarıdaki belgelere ek olarak; yüksek lisans tezi ya da yüksek lisans projesi ya da tek yazarlı bilimsel yazı (hakemli dergide makale, hakemli bir konferansta bildiri, kitap bölümü, araştırma makalesi vb.) istenmektedir.

Mezuniyet İçin Gerekli Kredi Yükleri: Yüksek lisans ve doktora programını tamamlama ile ilgili çeşitli üniversitelere göre farklı toplam saat, birim ya da kredi gibi ifadeler kullanılmıştır.

- Yüksek lisans için: 15 ya da 30 saat, 45 birim, 24 kredi, 36 kredi, 32 ya da 36 dönem saat

- Doktora için: 45 saat, 135 birim, 18 kredi, 32 kredi, 60 kredi, 96 ya da 54 dönem saat

Yüksek Lisans ve Doktora Programlarında Öne Çıkan Özellikler

Yurt dışındaki 11 üniversitenin yüksek lisans ve doktora programları incelendiğinde, bazı özellikler dikkat çekmektedir. Yüksek lisans programları için;

- Araştırma projesine dayalı bir yayın hazırlanmalıdır (WisconsinMadison Un.). 
- Kapsamlı bir sınav başarılmalıdır (Sınav 3 şekilde yapılmaktadır: 4 saat yazılı sinav ya da bir haftalık evde yapılabilecek sinav ya da 1,5-2 saatlik sözlü sinav) (Wisconsin-Madison Un.).

- Tez, makale ya da proje ortaya konmalı veya öğrenci yazılı sınava alınmalıdir.

- Öğrencilere belirli alanlarda (İngilizce, matematik, fen vb.) uzmanlaşma fırsatı verilmektedir (Stanford).

Doktora programları için;

- "Doktora tezini okuma komitesi" oluşturulmaktadır. Bu komite tezi okumayı kabul etme ve "sözlü sınav komitesi"ne bunu iletmekle görevlendirilmiştir. Tez öğrencisi "Doktora Tezini Okuma Komitesi"nden onay almalıdır (Stanford Un.).

- Orijinal, araştırmaya dayalı, yaklaşık 7000-8000 kelimelik bir makale yazılmalı/bildiri hazırlanmalıdır (Stanford Un. ve Illinois Un.).

- Öğrenciler "tez seminer" dersini almak için en az 2 araştırma dersi almalıdir (Columbia Un.).

- Tüm öğrenciler eğitim tasarımı ya da değerlendirmenin özel bir alanında yeterlik göstermeli ve eğitim alanındaki araştırma yöntemlerinde yeterliğe sahip olmalıdır (Stanford Un.).

- İlk yılda öğrenci ve danışmanı tarafından oluşturulan "denetleyici komite", öğrencinin programdaki çalışmalarını onaylar. Bu komite kapsamlı sınavlar ve tez çalışması için öğrenciye rehberlik eder ve onun çalışmalarını değerlendirir (British Columbia Un.).

Yüksek Lisans ve Doktora Programlarında Zorunlu ve Seçmeli Dersler

$\mathrm{Bu}$ bölümde, incelenen 11 üniversitenin yüksek lisans ve doktora programlarında yer alan bazı ders örneklerine yer verilmiştir.

Tablo 14. Yurt dişı üniversitelerinin yüksek lisans ve doktora programlarında yer alan zorunlu derslerinden örnekler

\begin{tabular}{ll}
\hline Zorunlu Dersler (Yl) & Zorunlu Dersler (Dr) \\
\hline Toplum, Bilgi ve Teknoloji & Güncel Eğitim Programı Kuramı \\
Çok Kültürlü Eğitim & Eğitim Araştırmasında Veri ve \\
Özel Araştırma Sorunları (Eğitim Programı & Yorumlama \\
Odaklı) & Eğitimde Nitel Araştırmanın Temelleri \\
Eğitim Programı Çalışmalarında Seminer & Eğitimde Nicel Araştırmanın Temelleri \\
Öğretim Uygulaması Üzerine Araştırma & Çok Kültürlü Eğitim \\
\hline
\end{tabular}


Tablo 14'te görüldüğ̈̈ gibi, yüksek lisans ve doktora programlarında yer alan bazı zorunlu derslerden örnekler verilmiştir. Örneğin araştırma dersleri (Eğitimde Nitel/Nicel Araştırmanın Temelleri gibi) Türkiye'deki programlarda verilen derslerle benzerlik göstermektedir. Bunun dışında hem yüksek lisans hem de doktora programlarında çok kültürlü eğitime ya da daha özel konulara yönelik derslere yer verildiği görülmektedir.

Tablo 15. Yurt dişı üniversitelerinin yüksek lisans ve doktora programlarında

\begin{tabular}{ll} 
& yer alan seçmeli derslerinden örnekler \\
\hline Seçmeli Dersler (YI) & Seçmeli Dersler (Dr) \\
\hline $\begin{array}{l}\text { Kentsel Bölgelerde Eğitim Programı ve } \\
\text { Öğretim }\end{array}$ & Çok Kültürlü Eğitim Programı ve Öğretim \\
$\begin{array}{l}\text { Öğrencilerin Öğretiminde Çok Kültürlü } \\
\text { Yaklaşımlar }\end{array}$ & Eğitim Programı ve Ulusal Sınavlar \\
Üstün Yetenekli Öğrenciler için Eğitim & \\
$\begin{array}{l}\text { Programında Farklılaştırma } \\
\text { Cinsiyet, Farklılık ve Eğitim Programı }\end{array}$ \\
$\begin{array}{l}\text { Eğitim Programı ve Göçmenlik } \\
\text { Bölgesel/Yerel Okul Sistemlerinde Programı Politikası Çözümleme } \\
\text { Geliştirme } \\
\text { Eğitim Programı Politikası Çözümlemesi } \\
\text { Eğitim Programı Kararlarının Temelleri }\end{array}$ \\
\hline
\end{tabular}

Tablo $15^{\prime}$ te, yüksek lisans ve doktora programlarında yer alan bazı seçmeli derslerden örnekler verilmiştir. $\mathrm{Bu}$ derslerin, Türkiye'deki programlardan farklı olarak, çok kültürlülüŭge, ulusal sınavlara, üstün yetenekli öğrencilere, bölgesel sistemlere, farklılıklara yönelik, yani günümüz toplumlarında öne çıkan konularla eğitim programlarını birleştiren seçmeli dersler olduğu gözlenmektedir.

Tablo 16'da, yüksek lisans ve doktora programlarında zorunlu ya da seçmeli ders ayrımı yapılmadan yer alan bazı derslerden örnekler verilmiştir. $\mathrm{Bu}$ derslerin de daha çok ayrımcılığa, azınlık eğitimine, değerler ve demokratik vatandaşlık eğitimine yönelik olduğu, özellikle doktorada uygulamalı ve araştırmaya dönük derslere yer verildiği, Türkiye'deki araştırma dersleri arasında, en azından isim olarak yer almayan, karma araştırma yöntemlerine de yer verildiği dikkat çekmektedir. 
Tablo 16. Yurt dişı üniversitelerinin yüksek lisans ve doktora programlarında yer alan zorunlu/seçmeli derslerinden "örnekler

\begin{tabular}{ll}
\hline Zorunlu / Seçmeli Dersler (Yl) & Zorunlu / Seçmeli Dersler (Dr) \\
\hline Değerler ve Okullaşma & Resmi Açıklamalar ve Azınlık Eğitimi \\
\hline Okul Ortamında Ayrımcıllı̆g Karşı Eğitim & $\begin{array}{l}\text { Eğitimde Sanat: Kavramlar, Bağlam ve } \\
\text { Sistemler }\end{array}$ \\
\hline Özgün Değerlendirme & $\begin{array}{l}\text { Eğitim Programında Uygulama: Doktora } \\
\text { Düzeyi }\end{array}$ \\
\hline Üstün Yetenekli Öğrencilerin Öğretimi & $\begin{array}{l}\text { Eğitim Programında Bireysel Okuma ve } \\
\text { Araştırma: Doktora Düzeyi }\end{array}$ \\
\hline Karşlaştırmalı Eğitim: Üçüncü Dünya & Eğitimde Karma Araştırma Yöntemleri: Nitel \\
Eğitim Sistemlerinin Gelişimi & ve Nicel Araştırmaları Birleştirme \\
\hline Kimlik Oluşumu ve Azzılık Eğitimi & \\
\hline Sinıfta Cinsiyet Eşitliği & \\
\hline Demokratik Vatandaşlık Eğitimi & \\
*Not: Zorunlu/seçmeli ders ayrımı yapılmamıştır. &
\end{tabular}

\section{TARTIŞMA VE SONUÇ}

$\mathrm{Bu}$ araştırma, EPÖ ya da eğitimde program geliştirme alanında Türkiye'de ve yurt dişındaki mevcut lisansüstü eğitim programlarını belirli ölçütlere göre analiz etmek amacıyla gerçekleştirilmiştir. Buradan yola çıkarak EPÖ alanındaki lisansüstü programların çeşitli öğeleri için durum tespiti yapılıp, önerilerin geliştirilmesi düşünülmüştür. Türkiye'de EPÖ lisansüstü eğitim programları incelendiğinde, özellikle YÖK'ün Lisansüstü Eğitim Öğretim Yönetmeliği'nde belirtilen en az yabancı dil puanında üniversitelere göre bazı farklılıklar görülmektedir. Yüksek lisans için yabancı dil puanı 40 ile 70 puan arasında değişirken, doktora programı için ise en az 55 ile 65 arasında değişmektedir.

Diğer yandan YÖK'ün yönetmeliğinde lisansüstü programlara öğrenci alımında genel yetenek sınavı kapsamında yapılan ALES ile ilgili koşul, yabancı dil puanına göre daha kesin bir şekilde belirlenmiştir. Tabanın 55 ALES puanı olmas1 ve bu puanın en az \%50'sinin değerlendirmeye yansıtılması koşulu, bu konuda farklı uygulamaları engellemiştir.

Türkiye'de EPÖ lisansüstü programlarında açılan dersler birbirine oldukça benzerdir. Zorunlu dersler arasında bilimsel araştırma dersleri, alan dersi olarak da Eğitimde Program Geliştirme ve Ĕgitimde Program Değerlendirme, Program Değerlendirme/Yaklaşımlarl Program Değerlendirme: Kuram ve Uygulama dersleri programların en çok benzeyen dersleridir. Seçmeli derslerde ise HIE Programlart, Program Değerlendirme ve Karşılaştırmalı Eğitim, Türk Eğitim Sisteminin Yapısı Sorunları/Örgüt ve 
Yönetim Sorunları, Karşılaştırmalı Eğitim, Program Geliştirmede Yeni Yaklaşımlar dersleri ön plana çıkmıştır. Ortaklık gösteren dersler dışında bazı enstitülerde belirli yaklaşımlarla (kubaşık öğrenme, proje tabanlı öğrenme, eğitimde yapılandırmacılık) ilgili, öğretmen eğitimi, rehberlik ve psikolojik danışma ile ilgili seçmeli derslerin de yer aldığı belirlenmiştir.

Ayrıca Türkiye'deki lisansüstü eğitim programlarında alınması gereken ders/kredi sayısı, bu programları tamamlama süresi, yeterlik sınavı, tez izleme komitesi, tez süreci ve sonuçlanması ile ilgili koşullar YÖK'ün Lisansüstü Eğitim Öğretim Yönetmeliği'nde açık bir biçimde belirtilmiştir. Enstitüler de bu koşulları yönetmeliklerine yansıttıklarından söz konusu durumlara ilişkin koşullar enstitüler arasında büyük ölçüde benzerlik göstermektedir.

Türkiye'deki EPÖ yüksek lisans ve doktora programları ile yurt dışındaki üniversitelerin programları arasında, alınması gereken toplam krediler açısından, önemli farklılık gözlenmektedir. Yurt dışı lisansüstü programlarında tamamlama süresi belirtilmekten çok, mezuniyet için gerekli toplam kredi üzerinde durulmuştur. Lisansüstü programlara öğrenci kabulü açısından da Türkiye'deki üniversitelerle yurt dışındaki üniversiteler arasında farklılık gözlenmektedir. Yurt dışındaki programlara başvuruda sınavlardan çok niyet, referans/tavsiye mektupları ve yayınlar ön plana çıkmaktadır. Referans mektubu uygulaması ülkemizdeki bazı üniversitelerde gerçekleştirilen bir uygulamadır. Yurt dışında EPÖ'ye benzer olan programların isimleri farklılık göstermekte ve verilen derslerde de çeşitlilik gözlenmektedir. Diğer yandan, Türkiye ve yurt dışındaki programların özellikle eğitim programı ile araştırma dersleri benzerlikler göstermektedir. Ancak ideoloji, toplum, azınlıklar, cinsiyetçilik, çok kültürlülük vb. ile eğitim programı ilişkisini konu alan dersler ve karma araştırma yöntemleri ile ilgili araştırma dersleri yurt dışındaki programlarda belirgin olarak ortaya çıkmaktadır.

Yurt dişındaki programlarda araştırma derslerine verilen önem de dikkat çekicidir. Türkiye'de lisansüstü eğitim programlarında verilen araştırma derslerinin zorunluluğu konusunda ortak bir uygulamadan söz etmek olanaklı değildir. Diğer yandan, yurt dışında incelenen üniversitelerde lisansüstü eğitimde yeterli sayılmak için araştırma derslerinde başarılı olma koşulunu getiren üniversiteler de bulunmaktadır. Yapılan araştırmaların niteliğini doğrudan etkileyen bu uygulama dikkat çekicidir.

Türkiye'deki programlarda yüksek lisans ve doktora programını tamamlama süreci benzerdir. Yurt dışındaki programlarda ise lisansüstü programı tamamlama ile ilgili şu tür uygulamalar dikkat çekmektedir. Örneğin; yüksek lisans programı tez ya da proje ile tamamlanabilirken, doktorada tezin yanı sıra araştırma projesi, araştırma projesinden yayın, 
yeterlik sınavı dışında program mezuniyeti için yeni bir sınavdan geçme gibi uygulamalar gözlenmektedir.

Yurt dışında doktorada tez öncesi "tez okuma komitesi” ve tez sonrası "değerlendirme komitesi” oluşturulmasının yanı sıra, doktora programının başlangıcından itibaren öğrenciyi denetleyen ve yönlendiren bir komitenin olması göze çarpmaktadır. Bu noktada, Türkiye'de doktora düzeyinde sadece tez süreci için oluşturulan "Tez İzleme Komitesi” uygulamasının bu uygulamaya benzer olduğu söylenebilir.

$\mathrm{Bu}$ çalışmada EPÖ lisansüstü eğitim programlarının analizi sonuçlarına göre, Türkiye'de gerçekleştirilen uygulamalara çeşitli öneriler getirilebilir. Öncelikle, Türkiye'de EPÖ alanına özgü farklı amaçlara hizmet edecek programlar oluşturulabilir. Ayrıca, var olan programlarda ihtiyaç olduğu gözlenen farklı derslere, özellikle uygulamalı araştırmalara dayalı derslere yer verilebilir. Böylece üniversitelerin belirli konulara farklı bakış açılarını ortaya koyması sağlanabilir.

Doktora programlarına başvurularda, başvuran kişinin alanla ilgili yapmış olduğu çalışmalar, yayınlar vb. göz önüne alınabilir. Özellikle doktora programında öğrencileri ders aşamasında da izleyip rehberlik edecek komiteler oluşturulabilir. Lisansüstü programlarda mezuniyet öncesi tez çalışmaları dışında yayın yapma koşulu bazı enstitü yönetmeliklerinde açıkça belirtilmiştir. Bunların yaygınlaştırılması araştırma potansiyelinin gelişmesine katkı getirebilecektir.

Türkiye'de yüksek lisans ve özellikle doktora programlarında alınması gereken ders kredilerinin, yurt dışı programlarla da karşılaştırıldığında, arttırılması önerilebilir. Mevcut hali ile alınan ders sayısının alanı içselleştirmek için yeterli olmadığı söylenebilir. EPÖ lisansüstü programlarının niteliğini arttırmak için lisansüstü programların üç grup dersten oluşturulması önerilebilir. Birinci grup, eğitim programlarının temellerini oluşturan eğitim bilimi derslerinden oluşturulabilir. Eğitim felsefesi, eğitim sosyolojisi, eğitim politikası, eğitim tarihi vb. dersler bu grupta yer alabilir. Özellikle EPÖ alanında doktora programına devam eden öğrencilerin zorunlu olarak bu dersleri alması sağlanabilir. İkinci grup dersler, araştırma derslerinden oluşturulabilir. Nicel, nitel ve karma araştırma yöntemleri ile ileri istatistik gibi dersler bu grupta yer almalıdır. Doktora tez aşamasına gelen bir öğrencinin bu araştırma derslerini başarı ile tamamlamış olma koşulu aranmalıdır. Son grup dersler ise EPÖ'nün alan derslerini kapsayan derslerden oluşturulmalıdır. Ayrıca derslerin yüksek lisans ve doktora programı için farklılaştırılması da önerilmektedir. Mesleki ve teknik eğitim, yaygın eğitim, program teorileri, reform çalışmalarının analizi, öğretmenlerin mesleki gelişimleri vb. dersler EPÖ lisansüstü eğitim programlarının bir parçası olmalıdır. Böylece özellikle eğitim bilimi 
alanında lisans derecesine sahip olmayan ve EPÖ alanında lisansüstü eğitime başvuran öğrencilerin daha nitelikli ve bu alanı daha ileriye taşıyacak şekilde yetişmeleri sağlanmış olacaktır.

$\mathrm{Bu}$ çalışmada lisansüstü programlara ilişkin doküman analizi gerçekleştirilmiştir. $\mathrm{Bu}$ konuyla ilgili gelecekte yapılması düşünülen araştırmalarda, lisansüstü programın öğelerine ilişkin sorunları ve çözüm önerilerini belirlemeye yönelik olarak öğrenci ve öğretim üyeleriyle bireysel görüşmeler yapılıp derinlemesine çalışmalar gerçekleştirilebilir. Yine bu çalışmanın sınırlılıkları çerçevesinde dünyada ilk yüz (100) e giren üniversitelerin ilgili lisansüstü programları incelenmiştir. Bu ölçüte göre programlar incelendiğinde araştırma kapsamını çoğunlukla ABD'deki üniversiteler oluşturmuştur. Buna göre, ileride bu konuyla ilgili yapılacak araştırmalarda EPÖ alanında lisansüstü programa sahip dünyanın farklı bölgelerinden üniversiteler incelemeye alınabilir.

Sonuç olarak, EPÖ lisansüstü programlarında yer alan derslerde, alınması gereken kredi sayısında, öğrenci alımı ve mezuniyet ile ilgili koşullarda, özellikle doktora sürecinde öğrencilerin takibinde düzenlemeye gidilmesine ilişkin çalışmalar yapılabilir.

\section{KAYNAKLAR}

Arıcı, H. (2001). Sosyal Bilimler Alanında Bilim Adamı YetiştirmeLisansüstü Eğitim, Bilim Adamı Yetiştirme: Lisansüstü Ĕ̈itim (TÜBA, Bilimsel Toplantı Serileri: 7) (ss. 53-64). Ankara: Tübitak Matbaasi.

Drake, T.A. (2011). U.S. Comparative and international graduate programs: an overview of programmatic size, relevance, philosophy, and methodology. Peabody Journal of Education, 86(2), 189-210. [Online]: Retrieved on 17-August-2011, at URL: http://www.tandfonline.com/doi/abs/10.1080/0161956X.2011.561187

Gözütok, D., Alkın, S. ve Ulubey, Ö. (2010). Eğitim Programları ve Öğretim Alanının Amaçlarının Gerçekleştirilmesini Etkileyen Sorunların Belirlenmesi. Ulusal Eğitim Programları ve Öğretim Kongresi, Balıkesir.

Güven, İ. (2010). Türk Eğitim Tarihi. Ankara: Naturel Yayınc1lı.

Karakütük, K. (2002). Ö ğretim Üyesi ve Bilim İnsanı Yetiştirme: Lisansüstü Ögretimin Planlanması. Ankara: Anı Yayıncılık.

Karakütük, K. (2006). Türkiye Lisansüstü Öğretim Sistemleri. (Yayına Hazırlayan: Kasım Karakütük), Bazı Ülkelerin Lisansüstü Öğretim Sistemleri (ss. 389-411). Ankara: Ankara Üniversitesi Eğitim Bilimleri Fakültesi, Yayın No: 202. 
Karakütük, K. (2009). Lisansüstü Öğretimde Öncü Bir Kuruluş: Ankara Üniversitesi Eğitim (Bilimleri) Fakültesi (1969-1982), M. Ünal, V. Başpınar, H.S., Ozanoğlu ve S. Yılmaz (Ed.) Prof. Dr. Ali Naim İnan'a Armağan. Ankara: Seçkin Yayıncılık.

Karaman, S. ve Bakırcı, F. (2010). Türkiye'de Lisansüstü Eğitim: Sorunlar ve Çözüm Önerileri. Sosyal Bilimler Araştırmaları Dergisi, 2, 94-114, [Online]: http://sosyalb.gop.edu.tr/10.sayi/5-fehim.PDF adresinden 18 Ağustos 2011 tarihinde indirilmiştir.

Kavcar, C. (1976). Ankara Üniversitesi Ĕgitim Fakültesi (Derleyen, Cahit Kavcar). Ankara Üniversitesi Eğitim Fakültesi 10. Yıl Yayınları No:1, Ankara: Ankara Üniversitesi Basımevi.

Kısakürek, M. A. (1976). Üniversitelerimizde Yenileşme: Programlar ve Ö ğretim Açısından. Ankara Üniversitesi Eğitim Fakültesi Yayınları No:54, Ankara: Ankara Üniversitesi Basımevi.

MEB (1987). Milli Ĕ̆itim Temel Kanunu ile İlköğretim ve Ĕ̆itim Kanunu. Ankara: Milli Eğitim Basımevi.

Miles, H. B. \& Huberman, A. M. (1984). Qualitative data analysis: a sourcebook of new methods. California: Sage Publications.

Oğuzkan, F. (1981). Ĕ̆itim Terimleri Sözlü̆ğü. Ankara: Türk Dil Kurumu Yayınları.

Rosales, C.L. (1994). "Graduate school programs and doctoral research in curriculum studies in twenty-five leading research universities in the United States of America: A report of a post-doctoral fellowship research study." (ED 379 282). [Online]: Retrieved on 17-August-2011, at URL: http://www.eric.ed.gov .

Sağlam, M. (2007). Lisansüstü Eğitim Modelleri. Anadolu Üniversitesi Ĕ̆itim Bilimleri Enstitüsü Lisansüstü Ĕ̆itim Sempozyumu: Lisansüstü Ĕ̆itimde Sorunlar ve Çözüm Önerileri (17-20 Ekim 2007), 1-12.

Taymaz, H. (2007). Ankara Üniversitesi Eğitim Bilimleri Enstitüsü’nün Kurulması ve Çalışmaları. Anadolu Üniversitesi Ĕ̆itim Bilimleri Enstitüsü Lisansüstü Eğitim Sempozyumu: Lisansüstü Eğitimde Sorunlar ve Çözüm Önerileri (17-20 Ekim 2007), 13-17.

Varış, F. (1973a). Türkiye'de Lisansüstü Eğitim: Pozitif Bilimlerin Temel ve Uygulamalı Alanlarında. Ankara Üniversitesi Eğitim Fakültesi, Yayın No: 23, Ankara: Ankara Üniversitesi Basımevi.

Varış, F. (1973b). Türkiye'de Lisansüstü Ĕ̆itim: Sosyal Bilimlerde. Ankara Üniversitesi Eğitim Fakültesi, Yayın No: 34, Ankara: Ankara Üniversitesi Basımevi.

Yıldırım, A. ve Şimşek H. (2008). Sosyal Bilimlerde Nitel Araştırma Yöntemleri (6. Baskı). Ankara: Seçkin Yayıncılık. 
YÖK (1983). Lisansüstü Eğitim-Öğretim Enstitülerinin Teşkilat ve İşleyiş Yönetmeliği. 03.03.1983 tarihli ve 17976 sayılı Resmi Gazete, [Online]: http://www.yok.gov.tr/content/view/464/ adresinden 14 Mart 2011 tarihinde indirilmiştir.

YÖK (1996). Lisansüstü Eğitim Yönetmeliği. 01. 07. 1996 tarihli ve 22683 sayılı Resmi Gazete, [Online]: http://www.uak.gov.tr/yonetmelikler/lusinav.pdf adresinden 10 Ocak 2011 tarihinde indirilmiştir. 